\title{
The prevalence of depression and its association with quality of life among pregnant and postnatal women in China: a multicenter study
}

Research

Keywords:

Posted Date: January 21st, 2021

DOl: https://doi.org/10.21203/rs.3.rs-87042/v2

License: (c) (i) This work is licensed under a Creative Commons Attribution 4.0 International License.

Read Full License 


\section{Abstract}

The authors have requested that this preprint be withdrawn due to author disagreement.

\section{Full Text}

The authors have withdrawn this preprint from Research Square. 